\title{
A new species of Thelypteris (Thelypteridaceae) from southern Bahia, Brazil
}

\author{
Fernando B. Matos ${ }^{1}$, Alan R. Smith ${ }^{2}$, and Paulo H. Labiak ${ }^{3}$ \\ ${ }^{1}$ Herbário André Maurício V. de Carvalho (CEPEC), Centro de Pesquisas do Cacau, \\ C.P. 07, 45600-970, Ilhéus, Bahia, Brazil; e-mail: fbtms@yahoo.com.br \\ ${ }^{2}$ University Herbarium (UC), University of California, 1001 Valley Life Sciences Bldg. \#2465, \\ 94720-2465, Berkeley, California, USA; e-mail: arsmith@berkeley.edu \\ ${ }^{3}$ Universidade Federal do Paraná (UFPR), C.P. 19031, 81531-980, Curitiba, Paraná, Brazil; e-mail: \\ plabiak@ufpr.br
}

\begin{abstract}
A new species, Thelypteris beckeriana (Thelypteridaceae), is here described. It belongs to subgenus Goniopteris because of the presence of forked and stellate hairs on some parts of its blades. It is a narrow endemic to the Atlantic Rain Forest of southern Bahia, Brazil. A complete description, illustrations, and comparisons with the most similar species are provided.
\end{abstract}

Key Words: Atlantic Rain Forest, ferns, Goniopteris, taxonomy, Thelypteris beckeriana.

Recent collections of ferns from the State of Bahia, Brazil, have led to the discovery of a new species of Thelypteris subgenus Goniopteris (C. Presl) Duek. Remnants of the Atlantic Coastal Forest in southern Bahia are considered to be among the most important sites for biodiversity conservation in the world, especially for their outstanding species richness and high proportion of plant endemism (Mori et al., 1981, 1983; Thomas et al., 1998, 2008; Myers et al., 2000; Martini et al., 2007).

The species here described, as well as many others of subg. Goniopteris, emphasize the Brazilian Atlantic Forest as an important center of diversity and endemism for the group (Salino, 2002). At least 21 species in subg. Goniopteris are now known to be restricted, or nearly restricted (i.e., extending into Paraguay and northeastern Argentina), to this area.

In the State of Bahia, besides the species here described, at least eight others from subg. Goniopteris are known to occur: Thelypteris abrupta (Desv.) Proctor; T. anoptera (Kunze ex Kuhn) C. F. Reed; T. biformata (Rosenst.) R. M. Tryon; T. biolleyi (H. Christ) Proctor; T. kuhlmannii (Brade) comb. ined.; T. poiteana (Bory) Proctor; T. tristis (Kunze) R. M. Tryon; and T. vivipara (Raddi) C. F. Reed.

Thelypteris beckeriana F. B. Matos, A. R. Sm. \& Labiak, sp. nov. Type: Brazil. Bahia: Camacan, RPPN Serra Bonita, $9.7 \mathrm{~km} \mathrm{~W}$ de Camacan, na estrada para Jacarecí, $6 \mathrm{~km}$ SW na estrada para a RPPN e torre da Embratel, 15'23'30' $\mathrm{S}, 39^{\circ} 33^{\prime} 55^{\prime \prime}$ W, 700 m, $30 \mathrm{Jul}$ 2008, F. B. Matos \& R. R. Santos 1558 (holotype: CEPEC; isotypes: $\mathrm{UC}, \mathrm{UPCB})$.

(Fig. 1)

Species nova haec subgeneris Goniopteridis (C. Presl) Duek, Thelypteridis lugubri (Kunze ex Mett.) R. M. Tryon \& A. F. Tryon affinis, qua rhizomatibus suberectis vel erectis (repentibus in T. lugubri), faciebus pinnarum abaxialiter inter nervos dense pilosis, pilis furcatis vel stellatis ornatis et pilis furcatis ad capsulas sporangiorum differt.

Plants terrestrial; rhizomes decumbent or erect, caudices to $10 \mathrm{~cm}$ tall, $1-3 \mathrm{~cm}$ in diameter, apical scales brown, ovate, $2-3 \times 1-$ $1.5 \mathrm{~mm}$, bearing sparse furcate hairs ca. $0.1 \mathrm{~mm}$ long; leaves few (2-4), to ca. $150 \mathrm{~cm}$ long, monomorphic; petioles greenish-stramineous to light brown, to ca. $75 \mathrm{~cm} \times 6 \mathrm{~mm}$, densely pubescent to glabrescent with furcate or stellate hairs $0.1 \mathrm{~mm}$, also with a few long, stout hairs 


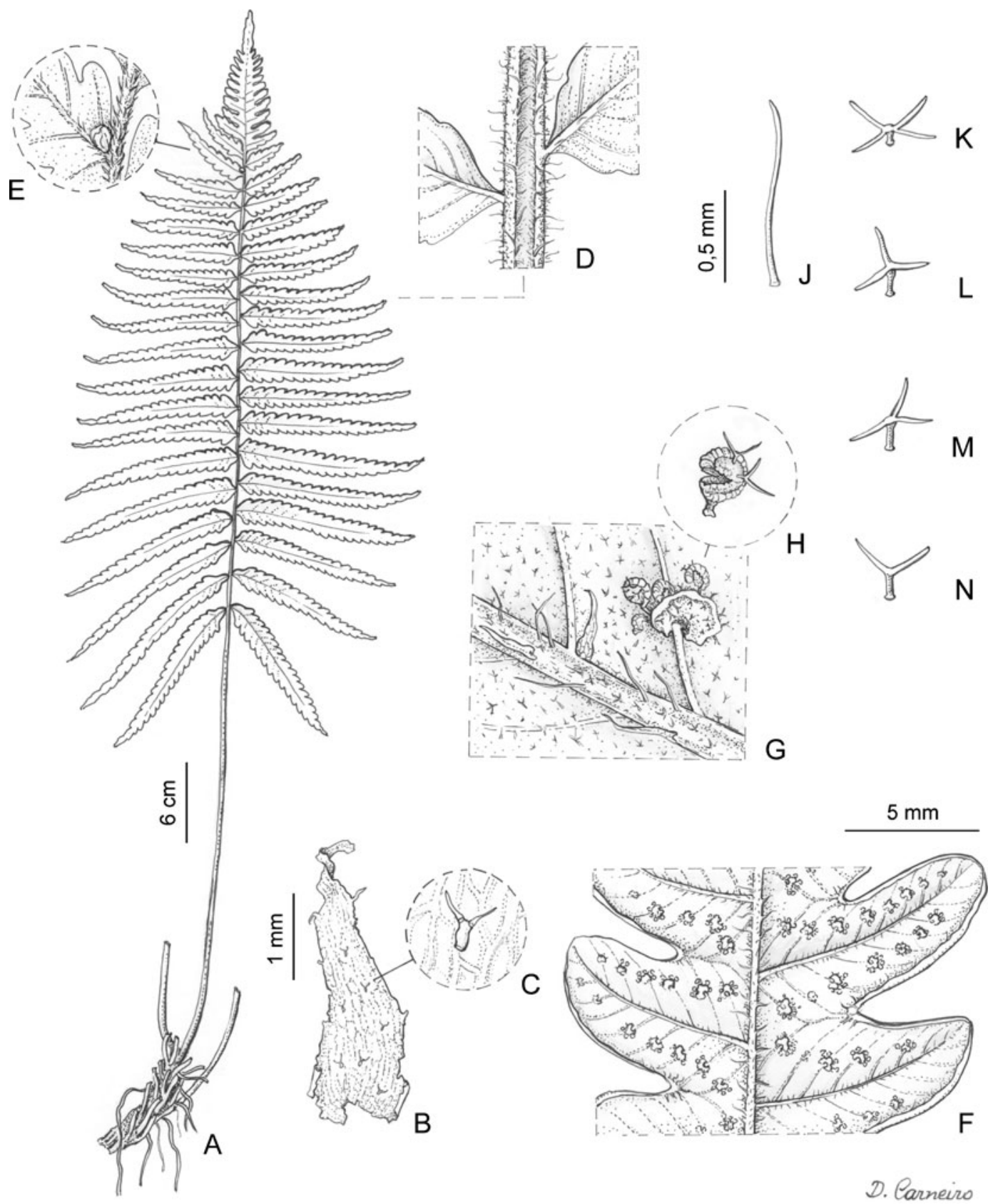

Fig. 1. Thelypteris beckeriana. A. Habit. B. Rhizome scale. C. Forked hair on surface of rhizome scale. D. Adaxial surface of rachis. E. Bud in the axil of a distal pinna. F. Pinna detail, abaxial surface. G. Lamina detail showing indument and sorus. H. Sporangium. J-N. Blade hairs. (Drawn from the holotype.)

to ca. $1 \mathrm{~mm}$, bearing scattered, ovate scales throughout; blades herbaceous, dark green, not verrucose, 1-pinnate-pinnatifid, the apex \pm gradually reduced and pinnatifid; buds or small plantlets present in axils of distal pinnae; rachises with dense, hyaline to often reddish, furcate or stellate hairs $0.1-0.2 \mathrm{~mm}$, also with a few longer acicular hairs; pinnae sessile or 
short-stalked $<1 \mathrm{~mm}$, subopposite proximally, alternate distally, spreading, 18-22 lateral pairs, $13-25 \times 1.5-3.5 \mathrm{~cm}$, incised 2/5-3/4 their width, bases narrowed but still pinnatifid, truncate, pinna apices attenuate, pinnatifid nearly to the tips, pinna lobes 4-7 mm wide at sinuses, about as long as broad, or usually longer than broad, rounded at apices; veins 713 pairs per segment, venation variable, even on the same frond, 1 pair united below the sinus with an excurrent vein to the sinus, a second pair running to the sinus, or lowermost pair running to sinus; indument abaxially on costae of inconspicuous brown, clathrate scales $0.5-$ $1 \times 0.1-0.3 \mathrm{~mm}$, scattered, stout, acicular hairs to $1.2 \mathrm{~mm}$ and shorter, dense furcate and stellate hairs $0.1-0.2 \mathrm{~mm}$, veins and surfaces between veins usually with acicular, stalked-furcate, and stalked-stellate hairs $0.1-0.2$, indument adaxially lacking except along costae, which bear dense, stout, acicular, ascending hairs to $1 \mathrm{~mm}$ long, and costules (scattered, stout, acicular hairs to $1 \mathrm{~mm}$ ); sori medial, round; indusia brown, bearing furcate hairs, evanescent; sporangial capsules setose, the hairs furcate.

Distribution and Ecology.-Known only from the moist forests of southern Bahia, Brazil, where it often grows along trails or in deep shaded places; 150-1000 m.

Etymology.-We name this species in honor of Dr. Vitor O. Becker, world-renowned entomologist, specialist in neotropical Lepidoptera, and owner of the Serra Bonita Reserve in southern Bahia, home of more than 180 species of ferns and lycophytes (Matos et al., in press), and the type locality of Thelypteris beckeriana.

\footnotetext{
Additional specimens examined. BRAZIL. Bahia: Almadina, Serra do Corcovado, $9.8 \mathrm{~km}$ ao SW de Coarací na estrada para Almadina daí $\mathrm{N}$ até a Fazenda São José, Proprietário Senhor Francisco, $14^{\circ} 42^{\prime} 21^{\prime \prime} \mathrm{S}, 39^{\circ}$ $36^{\prime} 12^{\prime \prime} \mathrm{W}$, 650-750 m, Jun 2005, Fiaschi et al. 2953 (CEPEC, UPCB); same locality, 19 Jul 2005, Matos et al. 720 (CEPEC, UPCB); Almadina, Serra dos Sete Paus, $6 \mathrm{~km}$ de Almadina na estrada para Ibitupã, daí $7 \mathrm{~km} \mathrm{~N}$ para a comunidade de Sete Paus, na nascente do Rio Almada, $14^{\circ} 44^{\prime} \mathrm{S}, 39^{\circ} 42^{\prime} \mathrm{W}, 578 \mathrm{~m}$, 19 Jul 2005, Matos et al. 712 (CEPEC, UPCB); Arataca, Serra do Peito de Moça, estrada que liga Arataca à Una, ramal ca. $22.4 \mathrm{~km}$ de Arataca com entrada no assentamento Santo Antônio, RPPN “Caminho das Pedras,” $15^{\circ} 10^{\prime} 25^{\prime \prime} \mathrm{S}, 39^{\circ} 20^{\prime} 30^{\prime \prime} \mathrm{W}$, 1000 m, 16 Feb 2006, Matos et al. 1028 (CEPEC, UPCB); Buerarema, Rodovia Buerarema-São José da Vitória (BR 101), ramal à direita, ca. $10 \mathrm{~km}$ da BR. Faz.
}

Santa Rosa, entrada ca. $500 \mathrm{~m}$ à direita, $15^{\circ} 06^{\prime} 19^{\prime \prime} \mathrm{S}, 39^{\circ}$ $16^{\prime} 20^{\prime \prime} \mathrm{W}, 150 \mathrm{~m}, 9$ Aug 2006, Labiak et al. 3698 (UPCB); same locality, 9 Aug 2006, Labiak et al. 3701 (UPCB); same locality as type, $850 \mathrm{~m}, 1$ Aug 2008, Matos 1587 (CEPEC, UC, UPCB).

Thelypteris beckeriana differs from Thelypteris lugubris (Kunze ex Mett.) R. M. Tryon \& A. F. Tryon by generally suberect or erect rhizomes (always creeping in T. lugubris), a bud or small plantlet in the axil of a distal pinna (buds variably present or absent in $T$. lugubris), duller blade surfaces adaxially, presence of scattered, stout, acicular hairs to $1 \mathrm{~mm}$ long on the costules adaxially, furcate hairs on the sporangial capsules, some furcate hairs on the indusia, rachis hairs more reddish, presence of forked or stellate hairs between the veins abaxially, and variable venation, with often one pair of veins united below the sinus. Thelypteris lugubris itself is quite variable in blade dissection, size, and pubescence, and is widely distributed in Brazil (Mato Grosso, Mato Grosso do Sul, Goiás, Minas Gerais, Rio de Janeiro, São Paulo, Paraná and Santa Catarina) and Paraguay. Another related species is $T$. montana Salino, from Espírito Santo, Minas Gerais, and Rio de Janeiro. It differs by dense stellate hairs between the veins abaxially and lack of long-acicular hairs on the costules adaxially, the rachis, and the costae abaxially. It further differs by glabrous sporangial capsules and lack of buds in the axils of the distal pinnae.

Other possibly related species include several Brazilian endemics: Thelypteris monosora (C. Presl) Salino, which has similar costal scales but differs by cuneate pinna bases, glabrous sporangial capsules, veins connivent at the sinuses, and costae and laminar tissue abaxially without stellate or furcate hairs. From T. cuneata (C. Chr.) C. F. Reed, Thelypteris beckeriana differs by cuneate pinna bases and glabrous sporangial capsules. Another species, Thelypteris multigemmifera Salino, has similar blade dissection, leaf length, and buds in axils of pinnae; however, it differs by creeping rhizomes, lack of costal scales, and the presence of stellate and furcate hairs on the costae, veins, and laminar tissue between veins abaxially. Also similar is T. paranaensis Salino, which differs by dense stellate and furcate hairs on and 
between the veins abaxially (but lacking acicular hairs), lack of laminar buds, and subconform terminal pinnae.

\section{Acknowledgments}

We thank André M. Amorim (UESC) and Wm. Wayt Thomas (NYBG) for supporting field work in southern Bahia and herbarium studies at The New York Botanical Garden as part of the project "Flora of the montane forests in Southern Bahia, Brazil" (Beneficia Foundation, NSF 0516233, NGS 7785-05, and $\mathrm{CNPq} 474648-4)$. We also thank CAPES for providing the Master's scholarship to the first author. We are grateful to Dr. William A. Rodrigues (UFPR) for the Latin diagnosis and Diana Carneiro for preparing the line drawings.

Open Access This article is distributed under the terms of the Creative Commons Attribution Noncommercial License which permits any noncommercial use, distribution, and reproduction in any medium, provided the original author(s) and source are credited.

\section{Literature Cited}

Martini, A. M. Z., P. Fiaschi, A. M. A. Amorim \& J. L. Paixão. 2007. A hot-point within a hot-spot: a high diversity site in Brazil's Atlantic Forest. Biodiversity and Conservation 16: 3111-3128.

Matos, F. B., A. M. Amorim \& P. H. Labiak. In press. The ferns and lycophytes of a montane tropical forest in southern Bahia, Brazil. Journal of the Botanical Research Institute of Texas.

Mori, S. A., B. M. Boom \& G. T. Prance. 1981. Distribution patterns and conservation of eastern Brazilian coastal forest tree species. Brittonia 33: 233-245.

A. M. Carvalho \& T. S. Santos. 1983 Southern Bahian Moist Forests. Botanical Review 49: $155-232$.

Myers, N., R. A. Mittermeier, C. G. Mittermeier, G. A. B. Fonseca \& J. Kent. 2000. Biodiversity hotspots for conservation priorities. Nature 403: 853-858.

Salino, A. 2002. New species and combinations in Thelypteris subg. Goniopteris (Thelypteridaceae). Brittonia 54: 331-339.

Thomas, W. W., A. M. Carvalho, A. M. A. Amorim, J. Garrison \& A. L. Arbeláez. 1998. Plant endemism in two forests in southern Bahia, Brazil. Biodiversity and Conservation 7: 311-322.

Diversity of woody plants in the Atlantic Coastal Forest of southern Bahia, Brazil. In: W. W. Thomas (ed.), The Atlantic Coastal Forests of Northeastern Brazil. Memoirs of the New York Botanical Garden 100: 21-66. 